\title{
MAYAN BELIEF SYSTEMS: A \\ NETWORK INTERPRETATION
}

\author{
John Stephen Brenna
}

University of Kansas

Mid-American Review of Sociology, 1979, Vol. IV, No. 2:17-37

\section{INTRODUCTION}

This paper is a network interpretation of the beliefs which might have been held by the horticulturists in the Maya lowlands. It is an exercise in discovering the consequences which would follow from certain types of beliefs. The paper takes as its problem: Could the beliefs of the workers using forest-fallow horticulture have allowed the development of a body of specialists in certain types of knowledge (such as astronomy, calendars, a number system, religious texts), and also have allowed the generation of enough surplus energy and its organization to support the construction of numerous religious structures and monuments? A possible system of beliefs is sketched that would explain what is known from archaeological research about the Maya lowland culture. This paper is an exercise in the interpretation of a social structure, based on Weber's $(1947: 154,156)$ conception of hierocratic systems using psychic coercion to direct action within the systems.

This paper will deal with a paradox: Why did the construction of religious structures and the development of cultural creations such as an accurate calendar and a useful number system flower in the Maya lowland rainforest? These features of Maya life were more highly developed than the corresponding features in other Mesoamerican civilizations such as Teotihuacan, the Toltec and the Aztec.

Let us begin with consideration of the labor time that a forest-fallow horticulture requires to supply food for subsistence. Katz (1972:29) indicates that a family of three, working in the Maya lowlands without irrigation, could produce food for two families with just 120 days of labor per year. Lenski (1966:145) 
estimates that a Maya corn farmer working 48 days per year could produce food for his entire family. Coe (1966:26) states that one farmer in the Peten region could produce food for 12 persons in a year's time. Though there are variations in annual rainfall in the lowlands, which could produce different labor requirements, it is safe to say that the slash and burn subsistence technology of the Maya could produce a considerable food surplus.

White $(1959: 293,297)$ discusses a similar case, the construction of pyramids by the Egyptians. He explains that the Egyptian form of agriculture produced surpluses, and that these were used to build pyramids. But other uses could be made of agricultural surpluses. The energy could support a bureaucratic army for extending the control of the state over its neighbors. Large transportation networks could be constructed (for example, see Katz, 1972, discussing the Inca). A trading empire such as that of Teotihuacan could be supported. Labor input could be decreased to just enough to allow surplus sufficient for continual parties.

Why did the Maya not use their potential for surplus to support a bureaucratic state and its army? An answer can be found in Carneiro's (1970) theory of the rise of the state. The presence of warfare is not enough to create a state that dominates neighboring groups. Circumscription of the groups to be taxed is also needed. First, there is environmental circumscription, like that which the Inca used in Peru (Carneiro, 1970:735). Next it is possible to think of resource concentration circumscribing a people who are not actually environmentally surrounded (Carneiro, 1970:736). Finally, there is the possibility of social circumscription; groups can be taxed by conquerors if they are circumscribed by other groups who are fierce (Carneiro, 1970: 737). Notice that it is difficult for those attempting to form a state to circumscribe persons in villages who use swidden horticulture for subsistence. Such farmers do not store food and do not have a single time of the year which allows an outside power the chance to come and extract a portion of the yearly harvest as tribute. The bureaucratic army also becomes much less useful in a rainforest, because the farmers can hide in the jungle. Thus, because the Maya practiced swidden agriculture, state formation among them would have been unlikely. Sanders and Price (1968: $142,161)$ have suggested that Maya were not organized as a state.

There are other (non-state) systems of domination that can be used to extract surplus from villages of farmers to support an elite. Weber $(1947: 154,156)$ describes the "hierocratic" system in which order is enforced through the use of "psychic coercion"; holders of power in these systems can distribute or deny access to religious benefits. Control over religious sanctions can then serve as the basis of a system to extract surplus for a ruling elite. It is not necessary to have any of the forms of circumscription discussed by Carneiro to make a hierocratic system work. Because the farmers who will produce the surplus to support the elite in the system believe in the priests' ability to control religious sanctions, and because the farmers believe in the importance of these sanctions, circumscription is not necessary. The farmers' belief systems are the locus of the analogue of circumscription for the hierocratic system. We will see that such a system was important among the Maya.

The main problem of this essay is to explain why the Maya civilization developed as it did (rather than along alternative lines) given the initial conditions and exogenous conditions of the lowland area where they lived. I have already noted that the Maya food production technology initially required relatively few days of labor per year. More intensive labor could have generated surpluses, which could have been used for a number of alternatives. White's discussion of the analogous case of the Egyptians shows the building of pyramids as a possibility. Carneiro's theory rules out the possibility of the Maya developing a state, but the hierocratic system of domination discussed by Weber could have developed under conditions such as existed in the Maya lowlands.

Three main sections follow in the body of this essay. The first describes the conditions of initial settlement of the lowland area. This section uses simple models to understand the process of settlement. The second section presents what is known from archaeological investigations about the rise of Maya ceremonial activities. Some models will be put forth to explain the rise of priests and religious activities. The third section of the paper analyzes the flowering of the Maya civilization. 


\section{Ia. SETTLEMENT}

I suggest that archaeological data indicate a spreading of swidden horticulture groups by a budding process in the lowland Maya area. If a village population grew larger than the population which could be comfortably supported within the section of forest around the village, the village would form a "bud" which would move into a previously unsettled section of forest. Carneiro (1970:735) points out that it makes little difference to a group practicing slash and burn horticulture what part of the forest they use for subsistence. This initial settlement by budding was a long, slow process and is assumed to have begun around 1000 B.C. (Webster, 1976:109). The time is given the name of Middle Preclassic (from 900 B.C. to 300 B.C.).

What has been suggested concerning social structure and political power during this settlement period? (Katz, 1972:31) indicates that an earlier time period had only independent villages and that the later Classic period (from about A.D. 300 to A.D. 1000) had rule by a priestly class. This implies that the Middle Preclassic settlement period was one of transition. Others (Webster, 1976:109 and Sabloff and Rathje, 1975:78) also see the period from about 400 B.C. to 300 B.C. as containing the development of ceremonialism and of incipient ranking.

\section{Ib. SOME MODELS FOR SETTLEMENT}

First, we can explain why a particular group of swidden horticulturalists would chose to move into virgin forest. Willer (1977) discusses the possible relations among two hypothetical forest-fallow villages (conflict, exchange, coercion, and no relationship). Willer (1977) points out that such groups would choose either to exchange with their neighbors or to have no relation at all. The reason is the relatively high costs for conflict and the ability of one group to escape from being coerced.

Second, we can understand the process of budding which seems to have occurred when village population increased beyond a certain point. There are at least three costs associated with traveling a given distance $x$ from one's village to the location of one's food source. There is the cost of time spent doing the travel, which is proportional to the distance. There is the energy cost of travel and of carrying food from source to the village. Lastly, there is a social cost which comes along the the reduction in time available to spend on non-acquisition activity. To understand the social cost, imagine that the members of the village are in a helping network which requires inputs of time on the part of all members to remain operational. As greater amounts of time must be spent obtaining food from larger distances away from the village, less time is available to maintain social contact for the helping network. More negative sanctions begin to flow as old helping contacts are not maintained. The too-large village population would then divide into two separate groups along close kinship lines. ${ }^{2}$

This explains early settlement processes. What happened, though, when there was no more unclaimed forest available for settlement by budding?

The second major section of the paper answers this question. Certain archaeological findings are presented. These are interpreted using David Willer's "elementary theory" of social action in social networks (see Willer and Anderson, forthcoming). Willer's theory "is a problem solving device which can be applied to a variety of social relationships and social structures for purposes of ...explanation and prediction" (Willer and Anderson, forthcoming). The theory is a structurally conditioned social action theory; it uses a modeling procedure to generate models to stand for cases of social interaction.

We use the theory as follows. For a given case, we begin by stating the "believed potential network" for the actors in the model. This entails all "positive" and "negative sanctions" which are believed to potentially be able to flow from one actor to some other actor. A positive sanction (by definition) increases the receiving actor's "preference state"; a negative sanction decreases the receiving actor's preference state. "Salience of transmission" describes the effect (on the actor's preference state) which follows from that actor transmitting the sanction.

Subsets of the potential network are the "possible worlds" which can happen in an elementary theoretic model. Actors 
possess a "preference order" which indicates a ranking from most to least preferred among each actor's possible worlds. Willer's elementary theoretic actors follow an action principle: They act to maximize their expected change in preference state (see Willer and Anderson, forthcoming). Willer's theory has wide scope, and has been applied to diverse cases (see, for example, Stephens, 1979 and Willer, 1977).

\section{IIa. RISE OF CEREMONIALISM}

We are now dealing with the Late Preclassic period (from 300 B.C. to A.D. 300). The Olmec influence on the Maya faded about 400 B.C. and the civilization at Teotihuacan began around A.D. 50 (Sabloff and Rathje, 1975:78). The island of Cozumel was first occupied in this time period (Sabloff and Rathje, 1975: 78). This implies that there was little forest land which was still unclaimed. There are other archaeological indications that the lowland area may have been filled completely with swidden agricultural groups by this period. Webster (1976:110), who has studied fortifications at Becan (located approximately in the center of the Yucatan peninsula), states that warfare began in the lowland area during the Late Preclassic period. Fortifications dated from this period have also been found at Edzna, in central Campeche (Matheny, 1976:642). A number of other lowland sites (Santa Rosa Xtampak, Becan Dzibilnocac) appear to have been settled by this time by the pioneer slash and burn horticulturists (Matheny, 1976:640).

It is possible that the decrease in available forest for subsistence stimulated the advances in food technology. The first food storage capacity appears at Tikal about 200 B.C.; there is also evidence of a "kitchen garden" to augment the regular slash and burn technology (Haviland, 1975:27). The villages were developing methods to make their food supply more consistent over time than would be the case with swidden horticulture alone. Given these new food production and storage capabilities and the lack of open forest, we now must explain the rise of ceremonialism and a priestly class among the Maya.
Some authors (see Haviland, 1975; Webster, 1976; Harris, 1977) have seen the development of Maya ceremonial centers as following upon increases in population density. Haviland sees the uncertainty inherent in swidden horticulture as stimulating the development of ceremonialism. Webster sees warfare as resulting from increased population density, and he sees ceremonial centers as being an adaptive method for dealing with the problems of conflict.

Let us begin with Haviland's argument. Evidence from his investigations of Tikal supports the conclusion that the Maya religion developed in the lowlands during the Preclassic period (Haviland, 1975:12). Tikal, which later became an important religious center for the Maya, was being formed around 200 B.C. (Haviland, 1975:23). Haviland (1975:8) argues that the settlers of the area around Tikal were adapting to the forest conditions well enough to have a slow and steady population growth during the Preclassic period. Even though he indicates that the Maya form of horticulture was effective enough to support increases in population, Haviland (1975:9) indicates that there were uncertainties to be reckoned with, such as variability in rainfall amount and onset, insects and hungry animals. In Haviland's view, Maya religion developed in response to the uncertainty of the type of horticulture used for subsistence. Religion functions to motivate the farmers despite unfortunate circumstances, and also to calm them in the face of bad crop conditions.

\section{IIb. MODEL OF UNCERTAIN CROPS: THE "CHARISMATIC" PRIEST}

Let us model the reactions of the farmers, who believe in the gods' control of horticultural conditions, to bad crop conditions occurring after the ceremonies conducted by the priests. Figure 1 represents the potential social network among the farmers (the $F$ point), the priest (the $P$ point), the god who is believed by the farmers to exist (the dotted G point), and the land which supplies the crop contingent upon the labor of the farmers. The land is represented by a square point, $L$. The following sanction and information flows can occur in the network represented by 
Figure 1 . The priest, $P$, is believed to be able to contact the god, dotted G. ${ }^{3}$ The god is believed to be able to positively or negatively influence the quality of the crop produced on the land, L. The land can send food to the farmers, F. The farmers can work on the land and can send some surplus food to the priest to enable the priest to subsist without spending time as a farmer.

If we decompose the potential network of Figure 1 into possible worlds, we arrive at those represented in Figure 2. Figure $2 \mathrm{~A}$ represents a world in which the god positively influences the land, and the food flows from the land to the farmers with no labor on their part. Figure 2B represents a world in which the god positively influences the land, the farmers work on the land, and the land yields food to the farmers. Notice that the farmers know (in their belief system) that Figure $2 \mathrm{~A}$ is not possible (i.e., they cannot have food without some work). The farmers would like to have world $2 \mathrm{~B}$, but the priest informs them that the god will not positively influence the land unless the priest contacts the god. The farmers believe the priest because they have experienced bad crops in the past (which they believe were caused by negative influence sent from the god to the land). This brings us to the best world the farmers believe possible, the world of Figure 2C. Here, the farmers work the land, feed the priest, the land feeds them, and the god sends positives to the land. But what happens if the random bad crop occurs?

This world is represented in Figure 2D. The priest still is believed to be important, and therefore the farmers feed the priest (at some cost to themselves). The farmers work the land, but no useful crop results. Within the belief system of the farmers, the conclusion is that a negative flowed from the god to the land, and this implies that the priest was not in contact with the god.

World 2D is the farmer's least preferred world. Somewhat more desirable (but still bad) is world 2E. It represents the situation in which the farmers work the land but the land does not produce a useful crop; this is once again believed to be due to the negative influence flowing from the god to the land. In this world the farmers do not feed the priest, believing that he is not serving his function of keeping the positives flowing from the god.

We see that the preference order of the farmers as a group is as follows: They would most prefer a world which fed them with no work on their part (known to be impossible). Next, they would like a world in which they worked on the land and kept all of the food they produced. (The priest tells them and they believe that this world too is impossible, because the god will send negatives to the land to keep the crop from being useful.) The best world believed to be possible is one in which the farmers work, get food from the land and feed the priest. The next best world (represented by Figure 2E) is one in which the farmers work, get poor crop and do not feed the priest their scarce food. The worst world for the farmers is Figure $2 \mathrm{D}$ in which they must work, get a poor crop and feed the priest.

Haviland's ideas about Maya religious practices developing in response to uncertain growing conditions are not supported by the above analysis of the beliefs and preferences of the Maya farmers. As bad crops occur, the priests will not be supported, whereas in Haviland's view, religion allegedly motivates the farmers and keeps them calm if bad crop conditions occur. Analysis of the "charismatic priest" model, above, indicates the farmers would take bad crops as evidence of the priests' failure and then would cease feeding the (believed useless) priests. The priests would then have to work in the fields for their own support and would not have time to devote to keeping in contact with the gods.

\section{IIc. THE CLEVER PRIEST}

The above analysis indicates that farmers will not support a priest who appears ineffective in contacting the god. Suppose that some clever priest says to the farmers in his village, "It is not my fault that the crop was bad; I did the best I could to contact God from the floor of the jungle, but he did not hear me!" Either the priest or the farmers could then have the idea to build a platform to have the priest stand on while contacting the god.

Let us model the new situation. Consider the social network modeled in Figure 3. The points are as follows: the priest $\mathrm{P}$, the 
farmers $F$, the believed-in god $G$, the square point land $L$, and finally the newly introduced square point (the pyramid for the priest to stand on during ceremonies to contact the god) represented by "Pyr." The sanctions which can flow are as follows: Once again the god is believed to be able to send either positive or negative influence to the crops. The priest can contact the god with an information flow labeled I. The priest receives from the Pyr point the positive sanction of being able to stand closer to the god in heaven. The farmers work on the land, send food to the priest, and spend spare time increasing the height of the Pyr point by moving rocks and the like; all of these sanctions have a negative salience of transmission for the $F$ point. The land sends crops to the farmers.

Now we will consider the possible worlds associated with the potential network represented in Figure 3. The various worlds are indicated in Figure 4. We will discuss the worlds in the order in which they are preferred by the farmers, beginning with the farmers' best of all possible worlds. Remember that the farmers' belief system makes impossible any world better than world 4A. In this world the farmers work on the land, receive crops from it, and send some food to the priest. The priest is able to spend his time contacting the god. The god is believed to send positive influence to the land to make good crops. Remember from the previous analysis that the Maya's uncertain horticulture will make world 4A not occur sometimes. When this happens (i.e., when crops fail), the priest and the farmers are then moved to world 4B. In this world the priest must stand on the pyramid "Pyr" which the farmers construct in their spare time with surplus food energy from extra crops. In the long run, this is the best world in which the farmers can live, because they believe it necessary to contact the god, who will make positives flow to the land and create condtions for good crops.

But every few years there will be a poor crop. Given the belief system of the farmers, we are now in world 4D. In this possible world the farmers are working the land, building a higher pyramid than before. The farmers are also sending food to the priest who is busy standing on the ever taller pyramid trying to contact the god. The land is not sending good crops to the farmers..
In their world view, this is interpreted as the god sending negative influence to the land. This is the farmers' worst possible world.

Better than world $4 \mathrm{D}$, but not as desirable as world $4 \mathrm{~B}$, would be the world represented in Figure 4C. Here the land is not sending crops to the farmers. This is believed to be due to the god sending negative influence to the land. But the farmers, who still are working in the forest to grow food, are better off than in world 4D because they are not spending time working to increase the height of the pyramid, nor are they feeding the priest any of their scarce food.

The possible worlds, in order from most to least preferred, are as follows. Best is world $4 \mathrm{~A}$ in which the farmers work only on the land, but send food to support the priest who makes the contact with the god that allows good crops. From the anlaysis in section IIb, dealing with the farmers and uncertain crops, we know that the farmers cannot have their best world year after year. The next best world, 4B, in which the farmers spend some time and energy making a platform for the priest, can be realized some years, but not always because of years with poor crops. When the bad crop years come, the farmers believe that the god has not been properly contacted. What happens in this case? From the analysis of the potential network of Figure 1, and its possible worlds represented in Figure 2, we know that the farmers would despair and stop feeding the priest; they would merely work harder in the forest to get more of a poor crop. But in the present case, with the believed need for a taller pyramid, the third best world $(4 \mathrm{C})$ of only working to grow food becomes unrealizable. The farmers now believe that their only hope to once again have good crops is to build a higher pyramid. The farmers' worst world (4D), in which they work in the fields and on the pyramid in their spare time, is now the only world in which they can live. Some years would bring good crops (represented in world 4B) but in general all the farmers can hope for is a life of working in the fields, feeding the priest, and building ever taller pyramids to increase the chances of the priest making the needed contact with the god. Thus from the analytic perspective used here, the building of ever-higher pyramids will be the long-run outcome of intermittent crop failures and the Mayan farmers' belief system. 
Mid-American Review of Sociology

\section{IId. SHIFT FROM “CHARISMATIC" TO "CLEVER" PRIEST}

The given conditions of the Maya lowland ceremonial development are the villages practicing swidden horticulture under uncertain environmental conditions. The first system modeled considered a priest who could be thought of as "charismatic." The farmers believed that this priest who contacted the god was responsible for good crops. Imagine a village elder who has accumulated empirical knowledge of swidden horticulture and local growing conditions, who spends more and more time on ritual, and who has had a string of lucky years with good crops. Key is the need for this priest to continually prove his effectiveness. A year with a bad crop disconfirms the belief in this charismatic priest; the farmers stop supporting him, and he is forced to go back to working in the fields. Many generations of charismatic priests in many lowland Maya villages could have been part-time priests before someone hit upon the idea of the god (who was in a heaven above the treetops) being hard to contact from the floor of the jungle forest.

This new system of the "clever" priest has an important shift in responsibility for continued successful contact with the god. Now a bad crop does not indicate an ineffective priest, but merely an effective priest too distant from the god. The burden of responsibility for poor crops is shifted to the farmers who did not build a high enough platform for the still effective priest to stand on during ceremonies.

......... This system has an internal logic which makes pyramide construction continue during years with good or bad crops. Bad crops imply the need for a taller pyramid; good crop years indicate the success of a taller pyramid and imply that better crops would follow an even taller pyramid. The rise and fall of charismatic priests has become a system which allows permanent priests. Here we observe, in the model, a situation which would support the "psychic coercion" which Weber (1947:154-56) posits as the basis for a hierocratic system of rule by a priestly class. Analysis of the "clever priest" model implies that the Maya horticulturalists would perform some work on religious structures each

\section{Mayan Belief Systems}

year. This is work done to avoid the psychic coercion of no prayers from the priest for good crops. It is essential that both the priest and the workers be involved in efforts to have the god give good crops. I am not, however, arguing that the Mayan workers spent massive amounts of effort building pyramids; Erasmus (1965:278) has claimed that the Mayan ceremonial structures were built without massive effort.

\section{IIe. COMMENTS ON THE MODELS}

Continual building of ever taller religious platforms by the village farmers and supporting permanent priests are the conditions for some further developments that have been found in the Maya religious centers. The full-time priests can elaborate the specialized knowledge they possess. We will discuss the consequences for the priests and farmers, while the consequences for interdependent village groups will appear in section III below.

The early Maya were influenced by other civilizations in Mesoamerica. The knowledge of items such as the Olmec calendar was available to the (now full-time) priests. The "clever" priest system discussed above has priests who specialize in contacting the god, with the farmers being the necessary labor force to construct pyramids for ceremonies. The priests have an interest in developing an abstract god unreachable by anyone without specialized knowledge. The priests also have an interest in a division of labor within the priesthood with some full-time "scientist" priests (who continually elaborate the specialized body of knowledge) and "village" priests who perform religious ceremonies in the villages.

A priesthood with specialized knowledge and a division of labor were both characteristic of the Maya. Thompson (1936: 58-59) discusses the divisions among the priesthood. There were high priests held in esteem by all; these were usually the second sons of nobility and were highly educated scientist types. At the next level was the regular priesthood who conducted ceremonies and related activities.

The specialized knowledge developed by Mayan priests is astounding when compared to the swidden horticulture which 


\section{Mid-American Review of Sociology}

supported the priests who developed the knowledge. The Maya lacked practical knowledge such as the use of the wheel or the plow, yet had an elaborate philosophy of time and a welldeveloped knowledge of astronomy (Thompson, 1954:13). Many civilizations of Mesoamerica had a calendar which had a fiftytwo year cycle in it, yet the Maya elaborated this and created a "long count" which allowed specification of dates uniquely within historical time (Coe, 1966:54, 58). The Maya developed a hieroglyphic writing system (Von Hagen, 1960:195) that was the most advanced in Mesoamerica. Independently of outside in fluence, the Maya knowledge specialists invented a number system with a zero (Von Hagen, 1960:198-99; Coe, 1966:156). Coe states that the Olmec possibly knew of only a three-symbol number system (a shell for zero, a dot for one, and a bar for five) before the Maya (Coe, 1966:156).

We have indicated what could have developed from a system in which Maya farmers worked continually to support full-time priests. Now we will discuss the development of a hierocratic system of domination in the Maya lowlands.

\section{THE FLOWERING OF THE MAYA}

Given the increasing population, Webster (1976:110) argues the following. Swidden agriculture requires large amounts of land; there is conflict among villages for forest for subsistence. Organization of groups of villages into coordinated conflict activity has two adaptive consequences. First, there is a reduction of conflict among the villages organized into a single unit. Second, there is added ability to win conflicts with neighboring villages. Webster sees ceremonial centers in some villages as standing symbolically for the village alliance. He points out that the more successful centers would be adaptive in the conflict situation and that their ceremonial centers and religious leaders would then become more important.

Consider the following alternative explanation for the rise of certain villages as ceremonial centers among the Maya lowlands. There are two different possible conditions among the lowland villages. First, imagine a number of villages with populations
Mayan Belief Systems

averaging $n$ persons. The farmers in these villages work in their village plots to grow food and work to construct pyramids, ever taller, in their own village. Second, there could be a situation in which a number of villages have banded together to construct a pyramid in the "ceremonial center" village. Why would some villages do this? The answer lies in the moving force of the belief that taller pyramids are better pyramids, and in the costs of building them

A given level of food production technology and a village of $n$ persons can produce a maximum amount of energy from their own area of the forest. Let $E$ represent this energy; let Es represent the surplus energy available for constructing pyramids and let $E f$ represent the food energy needed for maintaining the village population. Equation (1) represents the fact that the total energy is food for maintaining population and energy for building pyramids.

$$
\text { (1) } E=E s+E f
$$

The Maya pyramids achieved height by piling rocks up in a location. Let us consider the relationship between the height of a given pyramid and the energy needed to build it. As a first approximation it seems valid to consider the energy input as being determined by the volume of the pyramid; the pyramid is rocks piled up and the larger the volume to fill up, the more rocks to be moved and hence the more energy input necessary. There is an interesting relationship between the height of a pyramid and the volume of the pyramid; see equation (2):

(2) $V=(1 / 3) b^{2} h$, where $V$ is the volume, $b$ the distance along one side of the base, and $h$ is the height.

This expression can be converted into one in which the volume is expressed only in terms of the height of the pyramid and the slope of the sides. Let the slope be defined as the unit change in height divided by corresponding change in horizontal distance. See equation (3) 
Mid-American Review of Sociology

$$
\begin{array}{ll}
\text { (3) } s=2 h / b & \begin{array}{l}
\text { which can be solved by the base in terms } \\
\text { of the height. }
\end{array}
\end{array}
$$

(4) $b=2 h / s$

Now consider the volume of a pyramid of height $h$. See equation (5).

$$
\text { (5) } V=(1 / 3)(2 h / s)^{2} h=(4 / 3) h^{3} / s^{2}
$$

Lastly, we can calculate the change in volume needed to produce a certain change in height of the pyramid (under the assumption of constant slope). Let $h_{2}=c h_{1}$. The volume of a pyramid $c$ times higher than pyramid 1 is:

$$
\text { (6) } V_{2}=(4 / 3)\left(c h_{1}\right)^{3} / s^{2}=c^{3}(4 / 3) h_{1}{ }^{3} / s^{2}=c^{3} V_{1}
$$

In particular, a pyramid $2 h_{1}$ tall will have a volume eight times that of a pyramid $h_{1}$ tall. The consequences in terms of labor on the part of a particular Maya village, whose farmers believe in the need for constructing tall pyramids, should be obvious. There is a rapidly reached limit to the height of the pyramid a village of $n$ persons will be able to erect using surplus energy within their village.

If hmax were the maximum height for a pyramid which could be constructed by a village of $n$ persons, what would be the height of a pyramid which the combined labor of eight such villages could erect? If we make the assumption of no energy loss in the movement of the laborers from seven outlying villages to one central village, then the combined surplus energy of the eight villages would produce a pyramid twice as high as the maximum height pyramid which any single village would be able to construct.

We are suggesting that the belief in the importance of tall pyramids could certainly have acted in concert with the adaptive nature of ceremonial centers among the Maya which Webster (1976) discusses. The next logical step would be to minimize transportation of laborers from outlying villages by creating an
Mayan Belief Systems

army of laborers in residence on a year-round basis in the main ceremonial centers. Each village would have to supply a number of laborers and the food for their needs. This would explain the population estimates for cities such as Tikal in the range of 30,000 to 50,000 (Sabloff and Rathje, 1975:73; Haviland, 1967:28) by the year A.D. 600 .

\section{CONCLUSION}

This essay is a theoretic interpretation of possible belief systems of Mayan horticulturalists. Willer's elementary theory (see Willer and Anderson, forthcoming) was used to analyze a number of models for situations faced by Mayan horticulturalists. We found that the workers, theoretically, would cease feeding a "charismatic priest" after bad crops, because the priest had failed to enlist the god's aid in producing good crops. The "clever priest" model indicated that work on religious structures was essential in bringing about a full-time priesthood. In this case the farmers work growing food and work building pyramids; if crops fail they are partially responsible, and therefore a year of poor crops does not casue the priest to lose credibility.

This theroetic interpretation of the belief system of the horticulturalists indicates they would continue to work growing crops and making better religious structures. Continuous support of full-time priests, even through years of bad crops, allowed development of specialized knowledge among the Mayan priests. One outcome of such development is the distancing of the workers from the god; this strengthens the position of the full-time priest as a necessary link between the horticulturalists and the god. Ceremonial centers could easily have come into being as an attempt to utilize an economy of scale in the construction of ever-better religious structures. The Maya did not have a state organization, yet the workers supported the priest-rulers to avoid psychic coercion: cessation of contact with the distant god. 


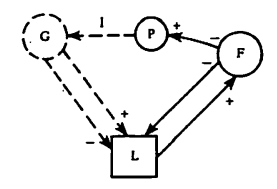

Figure 1. The $G$ point represents the god of the belief system of the $F$ point (the farmers as a group). The $P$ point represents the priest who is believed by the farmers to be able to make contact (the dotted information flow labeled I) with the god. The farmers do not like to work the land (the square $L$ point) but do enjoy food from the land. The priest receives food from the farmers. The god is believed to be able to positively or negatively influence the quality and quantity of crop from the land.
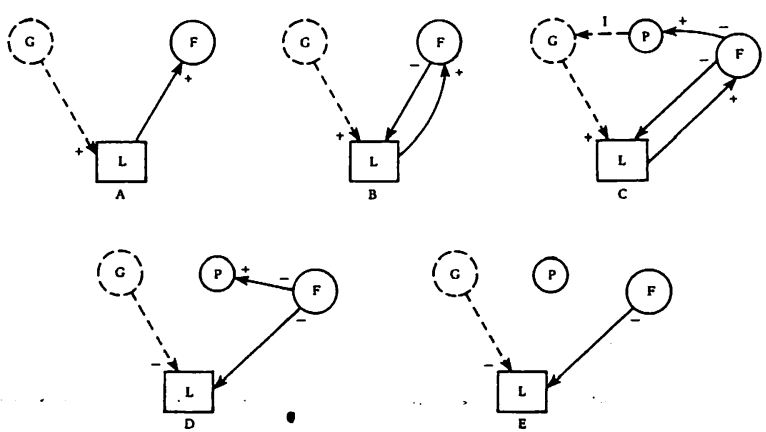

Figure 2. The possible worlds from the potential network represented in the Figure 1 interpreted above. $2 \mathrm{~A}$ represents the god's positive influence on the land causing food for the farmers with no work by the farmers. 2B represents the farmers working and receiving food, with the god having a positive influence on the land. $2 \mathrm{C}$ represents the priest in contact with the god and being fed by the farmers. The farmers are working the land and getting food under the positive influence of the god. 2D represents a bad crop (the god's negative influence on the land) resulting in the land not giving food to the farmers for their work. The priest is fed, but the farmers believe that the priest is not in contact with the god. $2 \mathrm{E}$ represents the world in which the farmers do not feed the priest and land does not feed the farmers.

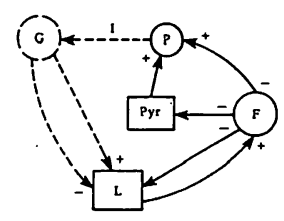

Figure 3. This represents a potential social network among the god G, the priest $P$, the farmers $F$, the forest land $L$, and the priest's ceremonial pyramid Pyr. The farmers work in the field, build the pyramid, and send food to the priest. They believe the god can do good and bad things to the land; they also believe the priest, if high enough off the jungle floor, will be able to contact the god. The pyramid helps the priest. The crops come from the land.
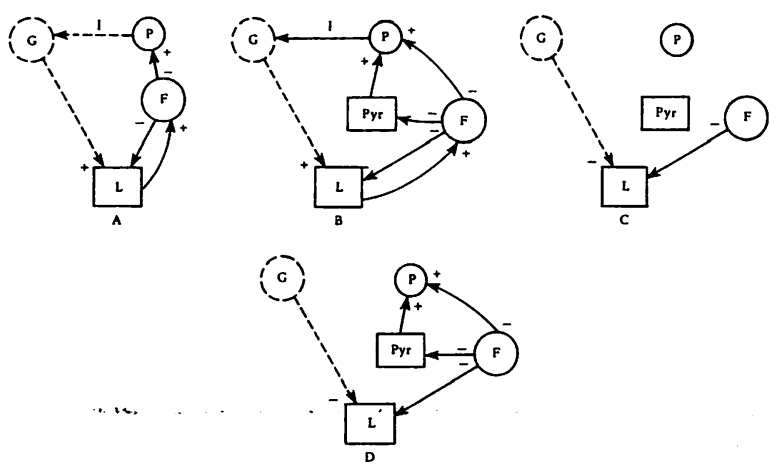

Figure 4. World 4A is the farmers' best world, given the belief that the god must be contacted to make good crops. World $4 B$ is next best, given the belief that the priest must be elevated to contact the god. World $4 \mathrm{C}$ is next best, given that there is no contact with the god and therefore negatives are making poor crops, at least the farmers do not have to feed the priest and work on the pyramid. World 4D is the farmers' worst world given their belief system and the poor crops which randomly occur. In this world the farmers work on the land, give scarce food to the priest and spend time and effort on increasing the height of the pyramid to allow the priest to make contact with the god to begin the flow of positives to the land which is believed to enable the growth of good crops. 


\section{NOTES}

1. I would like to thank David Willer, an anonymous reviewer for MARS, and Michael G. Lacy for valuable comments and suggestions on an earlier draft of this paper.

2. The discussion of the costs of acquisition of food for a relatively large village population leading to a natural budding process is based on ideas advanced in Southard's (1978) dissertation.

3. There are two possible belief systems here. In one the god has rule which must be understood (hence the priest must contact the god to learn the rules) in order to be followed in order to produce good crops. In the other belief system, the god actively takes a role in helping or hindering the growth of the crops for food. In this second case the contact by the priest is needed to keep the god happy to keep positives flowing to the land. For the purposes of this paper the general term "contact" will be used and the distinction between attempts to understand the rules of the god and the attempts to please the god will not be made.

\section{REFERENCES}

Carneiro, Robert L.

1970 "A theory of the origin of the state," Science 169:733-738. Coe, Michael D.

1966 The Maya. London: Thames and Hudson.

Erasmus, Charles

1965 "Monument building, some field experiments," Southwestern Journal of Anthropology 21:277-301.

Harris, Marvin

1977 Cannibals and Kings: The Origins of Cultures. New York: Random House.

Haviland, William A.

1975 The Ancient Maya and the Evolution of Urban Society. University of Northern Colorado, Museum of Anthropology Misc. Series, No. 37

Katz, Friedrich

1972 The Ancient American Civilizations. K. M. Lois Simpson (trans.) New York: Praeger.

Lenski, Gerhard E.

1966 Power and Privilege: A Theory of Social Stratification. New York: McGraw-Hill.

Matheny, Ray T.

1976 "Maya lowland hydraulic systems," Science 193:639-646.
Sabloff, Jeremy A. and William L. Rathje

1975 "The rise of a Maya merchant class," Scientific American 233:72-82.

Sanders, William T. and Barbara J. Price

1968 Mesoamerica, The Evolution of a Civilization. New York: Random House.

Southard, Frank A.

1978 A Study of Structural Determinants of Population Change. Ph.D. Dissertation, Department of Sociology, Lawrence: University of Kansas.

Stephens, W. Richard, Jr.

1979 "The rise of the Hittite empire: a comparison of theories on the origins of the state," Mid-American Review of Sociology $4: 39-55$

Thompson, J. Eric S.

1936 The Civilization of the Mayas. Chicago: Field Muesum of Natural History Department of Anthropology. Leaflet No. 25, Third Edition.

1954 The Rise and Fall of Maya Civilization. Norman: University of Oklahoma Press.

Von Hagen, Victor Wolfgang

1960 The World of the Maya. New York: Mentor New American Library.

Weber, Max

1947 The Theory of Social and Economic Organization. Talcott Parsons (ed.), A.M. Henderson and Talcott Parsons (trans.), New York: MaccMillan.

Webster, David L.

1976 Defensive Earthworks at Becan, Campeche Mexico: Implications for Maya Warfare. Publication 41, Middle American Research Institute, New Orleans: Tulane University.

White, Leslie A.

1959 The Evolution of Culture. New York: McGraw-Hill.

Willer, David

1977 "A network interpretation of Carneiro's theory of the origin of the state," American Anthropological Meetings, Houston. Willer, David and Bo Anderson

(forthcoming) Social Exchange and Social Networks: The Elementary Theory and Its Applications. New York: Elsevier. 